\title{
Performance of Eucalyptus clones according to environmental conditions
}

\section{Desempenho de clones de eucalipto em função de condições ambientais}

\author{
Thaise da Silva Souza', Magno Antonio Patto Ramalho', \\ Bruno Marco de Lima² e Gabriel Dehon Sampaio Peçanha Rezende ${ }^{2}$
}

\begin{abstract}
The aim of this study was to verify if the selection site of clones affects their performance when used in other regions and to estimate the contribution of climate and soil factors in clonal performance when these were evaluated under different environmental conditions. Growth data were used for assessment of 49 Eucalyptus clones in eight environments. Clonal tests were set up in a randomized block design, with 30 or 40 replications, and plots consisted of one plant. Data concerning the volume of trees at three years of age were considered. Regression equations between the dependent variable (volume) and the independent variables (environmental factors) were obtained. It was found that the clones showed great variation in volumetric performance in different environments. The clone $\mathrm{x}$ location interaction was significant, showing that response of the clones did not coincide in different locations. For most of the clones, the selection site did not propitiate greater adaptation to the region of origin. The response to environmental factors varied among clones, especially for altitude, rainfall, boron, and zinc. Two clones stood out as the most stable and adapted to the three regions of planted forest.
\end{abstract}

Keywords: Quantitative genetics. Eucalyptus breeding. Genotype x environment interaction. Stability. Adaptability.

\section{Resumo}

O objetivo do trabalho foi o de verificar se o local de seleção do clone afeta o seu desempenho quando utilizado em outras regiões e estimar a contribuição de fatores de clima e solo no desempenho clonal quando avaliados em diferentes condições ambientais. Foram utilizados dados de crescimento referentes à avaliação de 49 clones de Eucalyptus em oito ambientes. Os testes clonais foram instalados no delineamento de blocos casualizados, com 30 ou 40 repetições, e parcela de uma planta. Dados referentes ao volume das árvores, aos três anos, foram considerados. Equações de regressão entre a variável dependente (volume) e as variáveis independentes (fatores ambientais) foram obtidas. Constatouse que os clones demonstraram grande variação no desempenho volumétrico nos diferentes ambientes. A interação clones $x$ locais foi expressiva evidenciando que o comportamento dos clones não foi coincidente nos diferentes locais. Para a maioria dos clones, o local de seleção não propiciou maior adaptação à sua região de origem. A resposta aos fatores ambientais variou entre os clones, especialmente para altitude, precipitação, boro e zinco. Dois clones destacaram-se como os mais estáveis e adaptados às três regiões de reflorestamento.

Palavras-chave: Genética quantitativa. Melhoramento de eucalipto. Interação dos genótipos x ambientes. Estabilidade. Adaptabilidade.

\section{INTRODUCTION}

Wood from the Eucalyptus genus is used to supply most forest-based industries in Brazil; it is the genus most widely deployed and studied, as a result of good adaptation to different soil and climate conditions and high yield. The area planted to Eucalyptus in Brazil accounts for more than seven million hectares, and for over $70 \%$ of the commercial reforestation area (IBÁ, 2015).

Due to the economic importance of commercially planted Eucalyptus spp, interest and investments in genetic improvement and management plans for species of the genus have intensified and provided for development and improvement of techniques for evaluation and selection of clones with good phenotypes for silvicultural and technological traits. This has been a successful strategy.

${ }^{1} \mathrm{PhD}$ student in Genetic in Plant Breeding. UFLA - Universidade Federal de Lavras. Postal Code 3037 - 37200-000, Lavras, MG , Brasil. E-mail: thaisefloresta@gmail.com, magnoapr@dbi.ufla.br.

2PhD Researcher. Fibria Celulose / Technology Center. Rodovia General Euryale de Jesus Zerbine, km 84 SP66 - $12340-010$ - Jacareí, SP, Brasil. E-mail: bruno.lima@fibria.com.br, gabriel.rezende@fibria.com.br.

Sci. For., Piracicaba, v. 45, n. 116, p. 601-610, dez. 2017 DOI: dx.doi.org/10.18671/scifor.v45n116.01 
The volume productivity has increased from $20 \mathrm{~m}^{3} / \mathrm{h}$ /year of wood in 1960 to more than $45 \mathrm{~m}^{3} /$ ha/year presently (RAMALHO et al., 2012).

The progress in yield demands an intensive evaluation of clones before recommending them. The biggest challenge is to identify these clones for local companies with diverse requirements and, above all, to make projections for years to come when the trees will actually be available for logging. The clone $\mathrm{x}$ environment interaction exerts considerable influence on phenotypic expression; that is, the response of clones will certainly not be the same in different environments. This has been commonly observed in planted Eucalyptus forests in Brazil (SOUZA et al., 1993; NUNES et al., 2002; ROCHA et al., 2005; SANTOS, 2012).

Brazilian forestry companies plant thousands of hectares annually in different climate and soil conditions. However, breeding plans focus on a few sites only. The main question is whether the clones developed on one site can be recommended for others. Another question is if there are climate and soil factors that can explain the different responses of clones on different sites. Although research involving clone x environment interaction is relatively frequent in Eucalyptus spp. cultivation in Brazil and in other countries, these questions have not been adequately answered in most existing reports.

The aims of this study were: i) ascertain if clones selected in one area affected clone performance in other regions; and ii) estimate the contribution of various climate and soil factors to clonal performance when clones were evaluated under different environmental conditions.

\section{MATERIAL AND METHODS}

Timber growth data of Eucalyptus clones were provided by Fibria Celulose S.A. For this purpose, 49 clones were evaluated from different species and selection sources on three sites: Aracruz, Jacareí, and Três Lagoas. Of the clones evaluated, 21 are from the Aracruz breeding program (clones 1 to 20 and 49), 15 from Jacareí (clones 23, 25, 26, 27, 31 to 37, 41, 44, 45 and 48), and 13 from Três Lagoas (clones 21, 22, 24, 28, 29, 30, 38, 39, 40, 42, 43, 46 and 47). The clones evaluated come from pure populations of E. grandis, E. urophylla or the hybrids of these two species. In addition, clones 16 (hybrid E. urophylla $x$ E. dunnii), 17 (hybrid E. urophylla $x$ E. viminalis), 18 (hybrid E. urophylla $x$ E. globulus) and clones 19 and 20 (hybrids E. urophylla $x$ E. maidenii) were included.

The clones were distributed in eight environments of four Brazilian states: Bahia, Espírito Santo, São Paulo, and Mato Grosso do Sul (Table 1). These environments differ as to geography, climate, and soil fertility (Table 1). The clonal trials were established in 2010, using the a randomized block design, with one plant per plot and 30 or 40 replications, with $3 \times 3 \mathrm{~m}$ spacing between plants.

Tabela 1. Characterization of environments in which the experiments were performed within each region in accordance with the variables of altitude $(\mathrm{m})$, thermal summation $\left({ }^{\circ} \mathrm{C}\right)$, rainfall $(\mathrm{mm})$, boron $(\mathrm{mg} / \mathrm{Kg})$, iron $(\mathrm{mg} / \mathrm{Kg})$, phosphorus $(\mathrm{mg} / \mathrm{Kg}), \mathrm{pH}$, potassium $\left(\mathrm{cmolc} / \mathrm{dm}^{3}\right)$, and zinc $(\mathrm{mg} / \mathrm{Kg})$.

Table 1. Caracterização dos ambientes em que foram realizados os experimentos dentro de cada região de acordo com as variáveis altitude $(\mathrm{m})$, soma térmica $\left({ }^{\circ} \mathrm{C}\right)$, precipitação $(\mathrm{mm})$, boro $(\mathrm{mg} / \mathrm{Kg})$, ferro $(\mathrm{mg} / \mathrm{Kg})$, fósforo $(\mathrm{mg} / \mathrm{Kg}), \mathrm{pH}$, potássio $\left(\mathrm{cmolc} / \mathrm{dm}^{3}\right)$ e zinco $(\mathrm{mg} / \mathrm{Kg})$.

\begin{tabular}{|c|c|c|c|c|c|c|c|c|c|c|c|}
\hline $\begin{array}{l}\text { Environ- } \\
\text { ment }\end{array}$ & Site & Experiment & $\begin{array}{l}\text { Alti- } \\
\text { tude }\end{array}$ & $\begin{array}{c}\text { Thermal } \\
\text { Summation }\end{array}$ & Rainfall & Boron & Iron & $\begin{array}{l}\text { Phos- } \\
\text { phorus }\end{array}$ & $\mathrm{pH}$ & $\begin{array}{l}\text { Potas- } \\
\text { sium }\end{array}$ & Zinc \\
\hline 1 & & Aracruz-ES & 48 & 23800.39 & 3585.2 & 0.52 & 83.83 & 6.17 & 5.88 & 0.09 & 0.10 \\
\hline 2 & Aracruz & Mucuri-BA & 87 & 22747.78 & 2999.4 & 0.44 & 52.52 & 6.55 & 6.24 & 0.06 & 0.32 \\
\hline 3 & & São Mateus-ES & 74 & 23582.45 & 2879.3 & 0.33 & 105.04 & 5.22 & 5.88 & 0.05 & 0.34 \\
\hline 4 & & Jacareí-SP & 733 & 19702.60 & 4113.4 & 0.32 & 101.4 & 12.09 & 5.39 & 0.07 & 0.50 \\
\hline 5 & Jacareí & Capão Bonito-SP & 690 & 20004.78 & 4268.4 & 0.45 & 58.58 & 4.00 & 4.81 & 0.01 & 0.34 \\
\hline 6 & & Itapetininga-SP & 684 & 20482.90 & 4180.3 & 0.39 & 84.84 & 29.74 & 5.24 & 0.04 & 1.10 \\
\hline 7 & Três & Selvíria-MS & 367 & 25689.04 & 3729.1 & 0.25 & 17.17 & 4.28 & 6.13 & 0.04 & 0.16 \\
\hline 8 & Lagoas & Três Lagoas-MS & 337 & 28566.04 & 3660.7 & 0.45 & 55.55 & 5.13 & 5.39 & 0.05 & 0.20 \\
\hline
\end{tabular}

The thermal summation variable is the sum of the temperature that occurred in the environment during the evaluation period. This was obtained by the monthly average temperature $\left({ }^{\circ} \mathrm{C}\right)$ multiplied by the number of days in the month. Subsequently, the values corresponding to 36 months of evaluation were added up. The rainfall variable is the amount of rain that the environment received during the study period and was calculated based on the sum of the total rainfall of each month within the evaluation period. 
Circumference at breast height $(\mathrm{CBH})$ and tree height $(\mathrm{h})$ were measured to estimate the diameter at breast height (DBH) (SCOLFORO, 2005):

$$
D B H=\frac{C B H}{\pi}
$$

where $\pi$ corresponds to 3.1416 and the true volume $(\mathrm{V})$ of the trees, calculated by:

$$
v=\frac{\pi(D B H)^{2} h f}{4}
$$

where $f$ is the stem form value (0.46) used by the company. The variable $\mathrm{V}$ was selected for the analysis because it had a high positive correlation with DBH and $h$ (Scolforo, 2005; Machado; Figueiredo Filho, 2009). Analysis of variance was carried out for each and joint environment, using the following statistical model:

$$
Y i j=\mu+C_{i}+A_{j}+C A i j+\bar{e}_{i j}
$$

where $Y_{i j}$ is the observed value of clone $i$ in environment $j ; C_{i}$ is the fixed effect of the clone $i(i=1$, $2,3, \ldots 49) ; A_{j}$ is the fixed effect of the environment $j(j=1,2,3, \ldots 8)$; CAij is the fixed effect of the interaction between clone $i$ and the environment $j$; and $\bar{e}_{i j}$ is the mean experimental error. The source of variation of the clone was decomposed into origins and clones within origins. The accuracy $\left(r g g^{\prime}\right)$ of the analyses of variance in each environment was calculated by:

$$
r g g^{\prime}=\sqrt{1-\left(\frac{1}{F}\right)}
$$

where $F$ corresponds to the clone's mean square volume grow, divided by its mean square error.

The mean V performance of the clones was classified by the Scott e Knott (1974) grouping test, per environment and the mean of the environments. The clone $\mathrm{x}$ environment interaction (CE) was fractionated by the eco valence estimate (W) (WRICKE, 1964), which represents the percentage of contribution of each clone in each environment for the GC:

$$
W_{j}^{2}=\sum_{i=1}^{t}(g a)_{i j}^{2}
$$

where $(g a)^{2}$ if corresponds to the sum of squares of the interaction effects of clone $i$ with the environment $j$ in which it was evaluated.

GxE was evaluated using the methodology of Nunes et al. (2005), based on mean data, standardized by:

$$
z_{i j}=\left(\bar{y}_{i j}+\bar{y}_{. j}\right) / s_{. j}
$$

where $z_{i j}$ is the value of the corresponding standard variable for clone $i$ in environment $j ; \overline{\mathrm{y}}_{i j}$ is the average of clone $i$ in environment $j ; \overline{\mathrm{y}}_{{ }_{j}}$ is the average of environment $j$; and $s_{._{j}}$ is the genotypic standard deviation between the clone mean in environment $j$.

The environmental effect was decomposed into climatic and soil variables. It should be noted that initially more soil variables were involved. After linear regression analysis involving the mean of 49 clones, those which differ only in the extraction method and the significant estimated coefficient of determination $\left(R^{2}\right)$ were selected. Thus, the environmental variables selected for carrying out the regressions concerning volumetric performance of the clones were: altitude, rainfall, thermal summation, boron, iron, $\mathrm{pH}$, and zinc. With these factors, linear regression equations were estimated between the independent variable (X), environmental factor, and the dependent variable $(\mathrm{Y})$, volume of clones. Subsequently, multiple regression equations were estimated. Selection of variables was performed by the stepwise procedure (FERREIRA et al., 2015).

All analyses were carried out through the R (R DEVELOPMENT CORE TEAM, 2015) and Genes (CRUZ, 2013) softwares.

\section{RESULTS AND DISCUSSION}

In the evaluation of clones or progenies, the most important aspect is to have the highest accuracy $\left(r g g^{\prime}\right)$ possible, because $r g g^{\prime}$ represents the association between the phenotype and genotypes, because the phenotype is measured, but the genotype classification is the main objective of breeders 
(RESENDE; DUARTE, 2007). This objective was met in this study. The rgg' were higher than 0.97 in all analyses of variance, indicating high accuracy estimation of the genotypes performance from the measured phenotypes. The results also indicate that the use of one plant per plot, associated to high number of replications (minimum of 30), clones can be well distinguished. There is not much information in this regard (RESENDE, 2002). However, the results show also that there were no big variations in the classification of treatments using plots of one plant compared to plots ranging from five to even 100 plants (ANDRADE et al., 2006; MENDES et al., 2014).

To achieve the goals established for this study, all clones needed to exhibit significant difference in volumetric performance. This occurred in all experiments. Another requirement in this type of research is that environments in which the experiments are conducted be different and representative of the planted eucalyptus forest area in the company. These environments covered a wide range of variation in altitude, climate, and soil fertility and. These differences were highlighted in Analysis of Variance.

The variation between clones and environments made it possible to detect significant differences in the clone $\mathrm{x}$ environment interaction, indicating that clone performance did not coincide in the different environments. Observing classification of the averages of the clones in the environments (Table 2), interaction is clearly demonstrated. As there was wide variation in classification of the clones, it can be inferred that the interaction was predominantly complex (KANG; MILLER, 1984; VENCOVSKY; BARRIGA, 1992; CRUZ et al., 2004). In this situation, breeders should seek strategies to mitigate the effect of interaction.

Tabela 2. Mean wood volume $\left(\mathrm{m}^{3}\right)$ of Eucalyptus obtained in evaluation of the clones with the best $(22,8,49,37$, and 14) and worst (47,30,43,18, and 19) performances in eight environments, at three years of age.

Table 2. Média do volume de madeira $\left(\mathrm{m}^{3}\right)$ de eucalipto obtido na avaliação dos clones de melhor $(22,8,49,37$ e $14)$ e pior $(47,30,43,18$ e 19) desempenho em oito ambientes aos três anos de idade.

\begin{tabular}{|c|c|c|c|c|c|c|c|c|c|c|c|c|c|c|c|c|c|}
\hline \multirow{2}{*}{ Clone } & \multirow{2}{*}{$\begin{array}{c}\text { Overall } \\
\text { Mean }\end{array}$} & \multicolumn{16}{|c|}{ Environment } \\
\hline & & 1 & & 2 & & 3 & & 4 & & 5 & & 6 & & 7 & & 8 & \\
\hline 22 & 0.16 & 0.17 & $\mathrm{C}$ & 0.12 & $\mathrm{D}$ & 0.09 & $\mathrm{C}$ & 0.14 & $A$ & 0.18 & $A$ & 0.19 & $A$ & 0.20 & $A$ & 0.16 & $B$ \\
\hline 8 & 0.15 & 0.25 & $A$ & 0.18 & B & 0.13 & $A$ & 0.13 & B & 0.14 & B & 0.12 & D & 0.16 & B & 0.11 & D \\
\hline 49 & 0.14 & 0.23 & $A$ & 0.19 & $A$ & 0.12 & $A$ & 0.09 & $\mathrm{D}$ & 0.10 & C & 0.12 & C & 0.12 & D & 0.10 & $E$ \\
\hline 37 & 0.13 & 0.21 & B & 0.08 & $\mathrm{~F}$ & 0.09 & C & 0.11 & C & 0.15 & B & 0,12 & C & 0.15 & C & 0.12 & D \\
\hline 14 & 0,13 & 0.21 & B & 0.10 & $E$ & 0.10 & B & 0.14 & $A$ & 0.14 & B & 0.07 & $\mathrm{~F}$ & 0.14 & C & 0.11 & D \\
\hline 47 & 0.07 & 0.09 & $E$ & 0.11 & $E$ & 0.06 & E & 0.08 & $E$ & 0.07 & $E$ & 0.05 & G & 0.07 & $E$ & 0.06 & G \\
\hline 30 & 0.07 & 0.07 & $\mathrm{~F}$ & 0.01 & I & 0.03 & $\mathrm{H}$ & 0.07 & $G$ & 0.12 & C & 0.07 & $F$ & 0.11 & D & 0.09 & $F$ \\
\hline 43 & 0.07 & 0.10 & $E$ & 0.02 & I & 0.03 & $\mathrm{H}$ & 0.06 & $G$ & 0.03 & $\mathrm{~F}$ & 0.10 & D & 0.13 & D & 0.08 & $\mathrm{G}$ \\
\hline 18 & 0.05 & 0.04 & $G$ & 0.06 & $G$ & 0.05 & $\mathrm{~F}$ & 0.05 & $\mathrm{H}$ & 0.07 & $E$ & 0.05 & $G$ & 0.05 & $F$ & 0.05 & $\mathrm{H}$ \\
\hline 19 & 0.05 & 0.04 & $G$ & 0.11 & $E$ & 0.02 & $\mathrm{H}$ & 0.05 & $\mathrm{H}$ & 0.09 & D & 0.07 & $\mathrm{~F}$ & 0.03 & $\mathrm{~F}$ & 0.03 & I \\
\hline
\end{tabular}

Means followed by the same letter belong to the same group by the Scott \& Knott test (1974) at $5 \%$ probability.

One of the questions of this study is the origin of the clones; that is, whether the site where the clone was selected is reflected in its relative performance in different environments. In analysis of variance, the source of variation of the clone was decomposed into origins and clones within origins. The origin refers to clones that were selected in the region of Aracruz, Jacareí, and Três Lagoas. The origin source of variation was not significant, i.e., in the mean of the eight environments and clones of each origin, there was no difference in wood volume. In principle, this information allows us to infer that the three clone selection programs were equally efficient. However, clone performance in each region was very divergent. Still more important is whether there is origin $\mathrm{x}$ environment interaction, which did not occur. It was expected that the clones selected in a given region would exhibit superior performance under conditions most similar to where they had been selected, i.e., within the environments of each selection unit. It should be noted, nevertheless, that some clones, like numbers 8 and 49 from Aracruz and 22 from Três Lagoas were ranked among the best in the environments within the region in which they were selected. The origin $\mathrm{x}$ environment source of variation reflects what occurs on average and does not allow inference of specific behavior from clones to be detected. In planted Eucalyptus, no report in this regard was found, but in other plant species, such as common bean, it was found that the performance of the lines was higher in conditions similar to those where they had been selected (PIROLA et al., 2002; SILVA et al., 2011). 
The term "environment" reflects all the factors involved in the growth and development of trees, except genotype (KANG; GAUCH, 1996; BERNARDO, 2010). What has not been adequately identified, especially in Eucalyptus cultivation, is which environmental factors mostly explain genotype performance and, particularly, if the response to the environment differs between clones. As weather and soil fertility data were available for the eight environments, it was possible to identify the environmental factors that most explained the variation in clone performance by means of linear equations involving each environmental factor alone (Table 2). Many factors showed coefficients of determination $\left(\mathrm{R}^{2}\right)$ estimations close to zero, indicating that they explained little to no variation in volumetric performance in different environments. However, for some clones, the response to environmental factors was significant (Table 4). For example, the zinc content in soil showed $\mathrm{R}^{2}$ higher than 0,47 for clones $4,11,16,34$, and 48 . In the case of boron, $\mathrm{R}^{2}$ estimations greater than 0.40 were observed for clones 7, 17, 31, and 46. The same was noted for other environmental variables (Table 3 ). The question is how to explain these results considering that some of these variables were not directly involved at any time in selection. It could be argued that these results occurred by chance. However, from $\mathrm{R}^{2}$ estimations exceeding 0.40 , it can be inferred that $40 \%$ or more of the difference in mean volume between the environments of these clones was due to the factors considered in regression. One strategy to mitigate the effect of the environment on these clones would be by the use of fertilizers containing the nutrient in the areas where the clone in question was grown. It could also be argued that the other clones in which the estimate from $\mathrm{R}^{2}$ for any environmental factor was close to zero are tolerant to variations in that environmental component.

Tabela 3. Estimation of coefficients of determination $\left(R^{2}\right)$ of regression between Eucalyptus wood volume $(Y)$ and the different data of the environmental variables $(X)$ [altitude (ALT), thermal summation (TS), rainfall $(\mathrm{RF})$, boron $(\mathrm{BOR})$, iron $(\mathrm{FE}), \mathrm{pH}(\mathrm{pH})$, and zinc (ZIN)] in the eight environments for the clones with the best $(22,8,49,37$, and 14$)$ and worst $(47,30,43,18$, and 19) performance.

Table 3. Estimativa dos coeficientes de determinação $\left(R^{2}\right)$ da regressão entre o volume de madeira de eucalipto $(\mathrm{Y})$ e os diferentes dados das variáveis ambientais $(\mathrm{X})$ (altitude (ALT), soma térmica (ST), precipitação $(\mathrm{RF})$, boro (BOR), ferro (FE), pH (PH) e zinco (ZIN)) nos oito ambientes para os clones de melhor $(22,8$, $49,37$ e 14$)$ e pior $(47,30,43,18$ e 19$)$ desempenho.

\begin{tabular}{lccccccc}
\hline \multirow{2}{*}{ Clone } & \multicolumn{7}{c}{ Variable } \\
\cline { 2 - 8 } & ALT & ST & RF & BOR & FE & PH & ZIN \\
\hline 22 & 0.19 & 0.00 & 0.50 & 0.00 & 0.33 & 0.08 & 0.01 \\
8 & 0.33 & 0.01 & 0.06 & 0.20 & 0.01 & 0.25 & 0.24 \\
49 & 0.50 & 0.01 & 0.20 & 0.33 & 0.00 & 0.33 & 0.10 \\
37 & 0.00 & 0.00 & 0.17 & 0.11 & 0.01 & 0.02 & 0.09 \\
14 & 0.05 & 0.01 & 0.01 & 0.10 & 0.00 & 0.01 & 0.41 \\
47 & 0.19 & 0.03 & 0.15 & 0.06 & 0.01 & 0.28 & 0.23 \\
30 & 0.33 & 0.01 & 0.58 & 0.01 & 0.19 & 0.31 & 0.01 \\
43 & 0.02 & 0.10 & 0.16 & 0.06 & 0.11 & 0.01 & 0.01 \\
18 & 0.14 & 0.27 & 0.06 & 0.01 & 0.07 & 0.16 & 0.02 \\
19 & 0.04 & 0.31 & 0.01 & 0.12 & 0.02 & 0.02 & 0.09 \\
\hline
\end{tabular}

We also sought to obtain estimates of $\mathrm{R}^{2}$ considering multiple regression by the stepwise methodology (Table 4). Prior removal of the components of the environment among the 49 clones was performed, which explained less than $20 \%$ of the variance. Reinforcing what was previously mentioned, it was found that the clones differed in response to all the environmental factors. However, some of these factors, such as altitude, precipitation, $\mathrm{pH}$, boron, and zinc, affected a larger number of clones. No report of differential response of clones/Eucalyptus progenies to any climate or environmental factor was found, as in this study. The results indicate that in future clonal reviews, these environmental variables must be considered and, therefore, selection can be directed. Thus, if a clone responds more to a soil fertility factor, for example, recommendation of the clone will be accompanied by suggestion of a management practice for soil fertility. In so doing, the interaction can be mitigated.

Another way to mitigate the GxE interaction would be to carry out clonal zoning, or identification of specific clones for each region, using information from climatic and soil conditions. As noted, the clone $\mathrm{x}$ environment interaction within each region was also significant, especially in Aracruz (Table 2). Although feasible in most cases, under the present condition, zoning is not vi- 
able. In addition, zoning works for expected environmental factors, such as soil conditions, but not for unpredictable environmental factors, such as rainfall, temperature, and frost, i.e., the effect of the years (ALLARD; BRADSHAW, 1964).

Tabela 4. Estimation of coefficients of determination $\left(R^{2}\right)$ obtained in multiple regression equations between Eucalyptus wood volume $(\mathrm{Y})$ and environmental variables $(X)$ in the eight evaluation environments for the clones of the best $(22,8,49,37$, and 14) and worst $(47,30,43,18$, and 19) performance. Stepwise analysis.

Table 4. Estimativa dos coeficientes de determinação $\left(R^{2}\right)$ obtido nas equações de regressão múltipla entre o volume de madeira de eucalipto $(Y)$ e as variáveis ambientais $(X)$ para os clones de melhor $(22,8,49,37$ e $14)$ e pior $(47,30,43,18$ e 19) desempenho nos oito ambientes de avaliação. Análise de stepwise.

\begin{tabular}{lcl}
\hline Clone & $\mathbf{R}^{\mathbf{2}}(\boldsymbol{\%})$ & Variables in the model \\
\hline 22 & 79.72 & RF+FE \\
8 & 68,04 & ALT+BOR+PH+ZIN \\
49 & 89.05 & ALT+RF+BOR+PH \\
37 & 0 & $*$ \\
14 & 41.19 & ZIN \\
47 & 36.61 & PH+ZIN \\
30 & 64.92 & ALT+RF+PH \\
43 & 0 & $*$ \\
18 & 27.21 & ST \\
19 & 31.10 & ST \\
\hline
\end{tabular}

*The volumetric performance of clones 37 and 43 was not explained in the proposed set of environmental variables.

Another option is to identify the most adapted and stable clones. First of all, the difficulty is to conceptualize what adaptation and especially stability is (VENCOVSKY; BARRIGA, 1992; CRUZ et al., 2004). The most accepted concept of adaptation is genotypes that are fully adjusted to a given condition. Adjusted would imply that those genotypes have found all conditions for their development within a given environment. To gauge this concept, mean clone volume is a good estimate of adaptation. The higher the average, the better adapted the clone is. Under this premise, the clones with the highest overall mean in various environments have broad adaptation (Table 2). This principle was widely used by Troyer (1996) regarding how to select for increased adaptation. The conclusion is that clones/hybrids should be evaluated in the highest number of replications/environments to identify those with the highest overall mean. In this study, this criterion was clearly demonstrated for clones 8 and 22, which stood out within the most productive group (Table 4). In this case, the mean was obtained from data collected in 250 replications (seven environments with 30 and one with 40 replications). Evidently, a recommendation based on data of this magnitude provides greater security for decision making of breeders. These results also allow us to conclude that if a company wishes to make use of few clones in the planted forest, these two clones could be recommended for all regions.

The concept of stability has been more controversial. For greater inclusiveness, Lin et al. (1986) classified aspects of this concept as: i) biological stability when the genotype response does not change in different environments; ii) agronomic stability when clone performance accompanies improvement in predictable environmental factors; and iii) genotype with greater predictability of response to different environmental changes, foreseeable or unforeseeable. The literature contains several methodologies for evaluating each of these types of stability (KANG; GAUCH, 1996; CRUZ et al., 2004; BERNARDO, 2010; RAMALHO et al., 2012). This study emphasized a methodology that in spite of having been proposed over fifty years ago (WRICKE, 1964) is still widely used because it allows identification of genotypes or environments that contribute most to the interaction. Ultimately that is what breeders want. In this case, this translates into clones with the smallest possible contribution to the interaction. The contribution to the interaction of clones 8 and 22, those with the highest means, was not higher than $2.5 \%$ when considering the 49 clones evaluated. Although this value was not the lowest magnitude, it was below average (Figure 1). When considering the three clones of lowest overall means, their contribution to the interaction was variable. Clones numbers 19 and 20 had a relatively high contribution to the interaction (Figure 1). It should be noted that these two clones are hybrids between trees of E. urophylla and E. maidenii. The latter species was most recently used in the company's breeding program, and therefore at the time of crossing, the hybrid had not been adapted. 


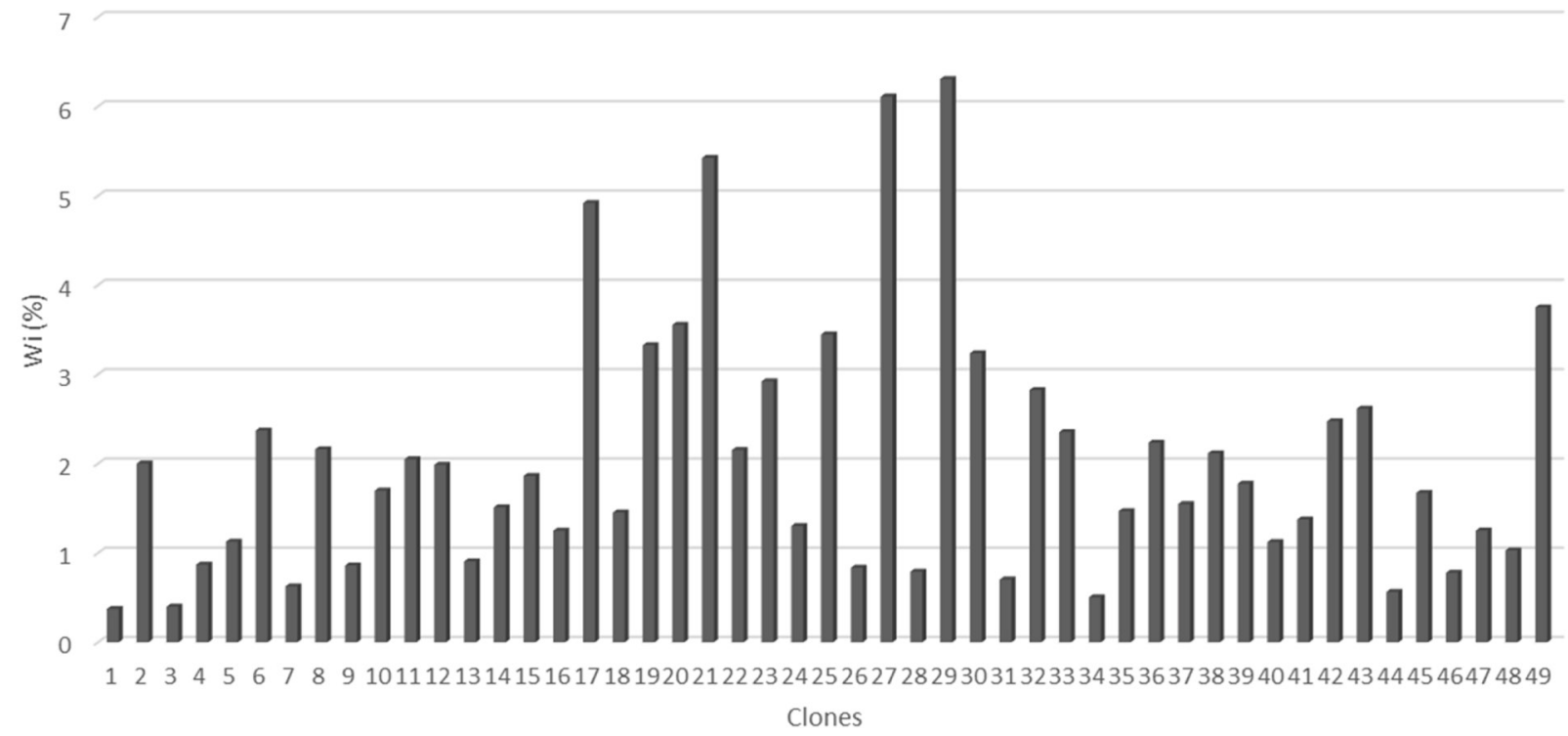

Figura 1. Mean percentage contribution of clones to the GXE interaction and Eco valence (Wi). Wood volume data at three years of age, obtained in evaluation of 49 clones of Eucalyptus in eight environments.

Figure 1. Contribuição percentual média dos clones para a interação GxA, Ecovalência (Wi). Dados de volume de madeira aos três anos de idade, obtidos na avaliação de 49 clones de eucalipto em oito ambientes.

Through the Wricke methodology Wricke (1964), it is possible to identify environments that contribute most to the interaction, as already mentioned. Environments 1 and 2, both from the Aracruz region, were the main contributors to the GxE interaction (Figure 2). This information is important because it shows breeders that the choice of these sites for conducting experiments was relevant and that in future, they should be used to select clones with greater stability. All these results can be interpreted visually by the graphic method proposed by Nunes et al. (2005). Note that clones 8 and 22 , already mentioned as being adapted and stable, fit the response of "full ball", that is with a mean above the overall mean, with small fluctuations in response to environments (Figure 3). The choice of the most adapted and stable clones is visually performed in a didactic manner. Clones 18 and 19, in contrast, have a response typical of "deflated ball", i.e., they have below average performance and usually show a wide fluctuation in performance among environments. As already mentioned, they are clones of high risk in the process of recommendation for use in planted forests.

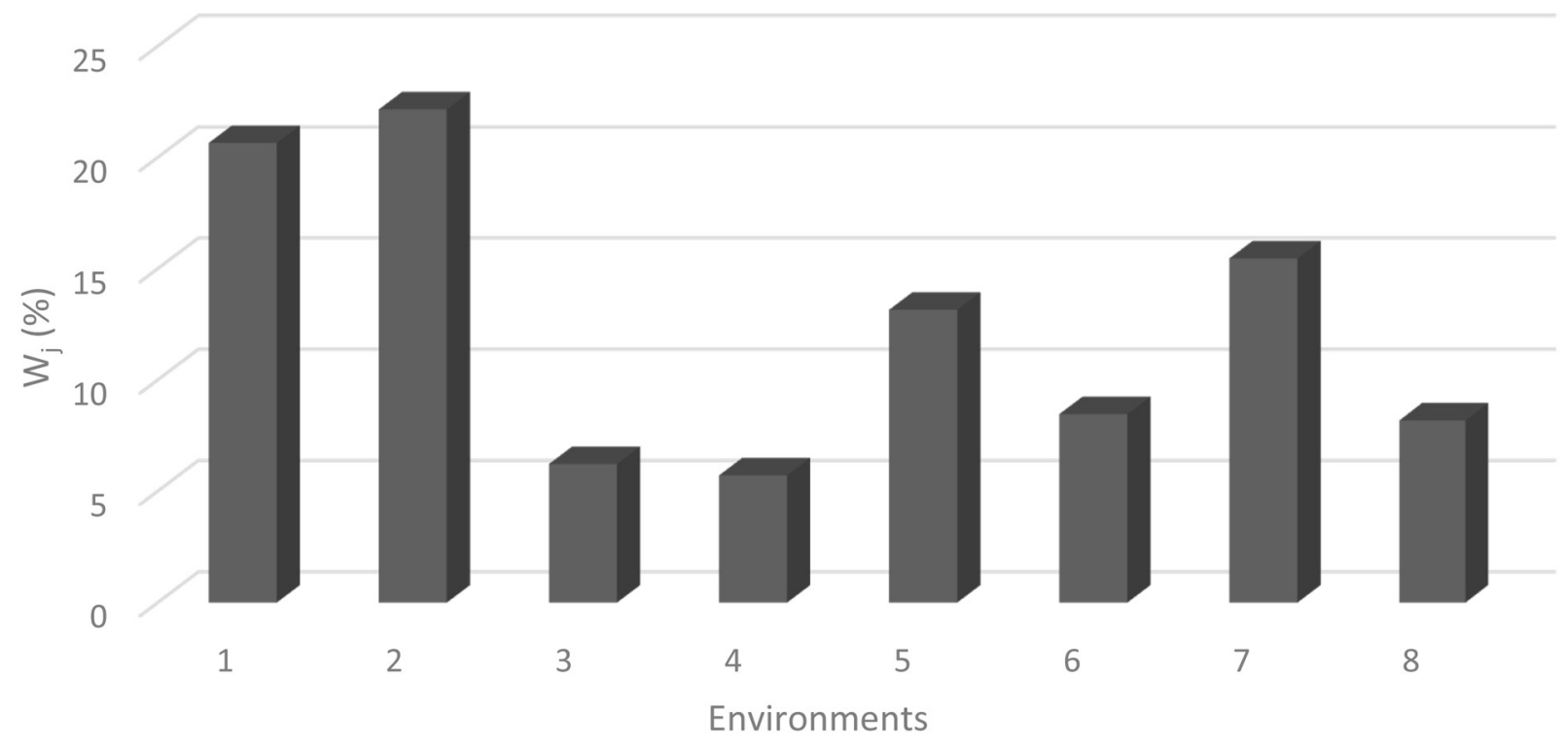

Figura 2. Mean percentage contribution of environments to the $G \times E$ interaction, Eco valence (Wj). Wood data volume at three years of age obtained in evaluation of 49 clones of Eucalyptus in eight environments.

Figure 2. Contribuição percentual média dos ambientes para a interação $G \times A$, Ecovalência (Wj). Dados de volume de madeira aos três anos de idade, obtidos na avaliação de 49 clones de eucalipto em oito ambientes. 


\section{Clone 8}

a1

a3

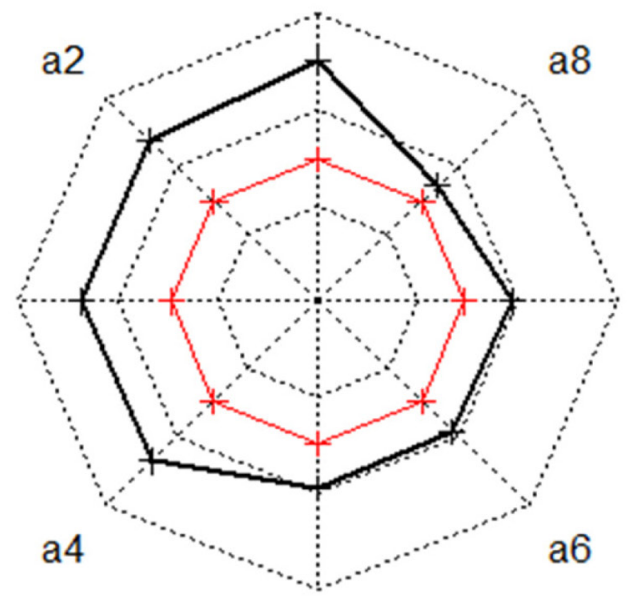

a5

\section{Clone 18}

a1

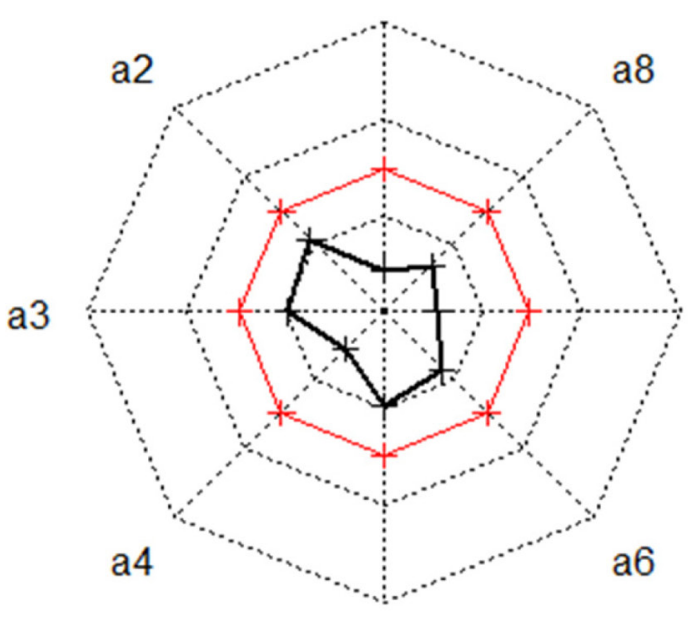

a5
Clone 22

a1

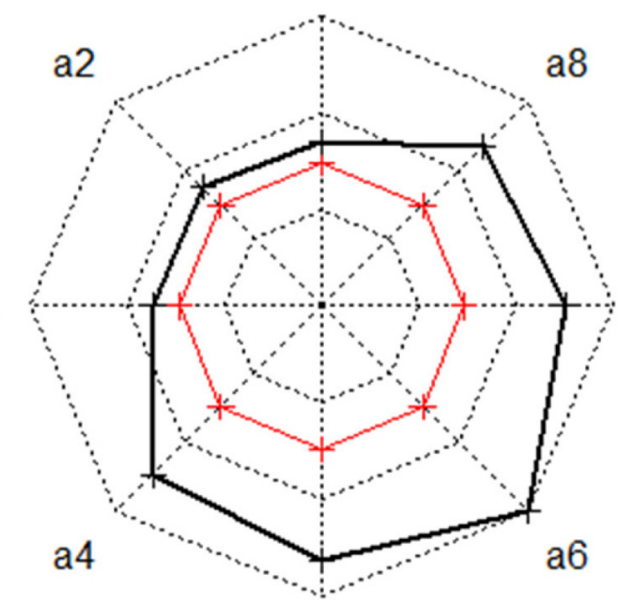

a5

Clone 19

a1

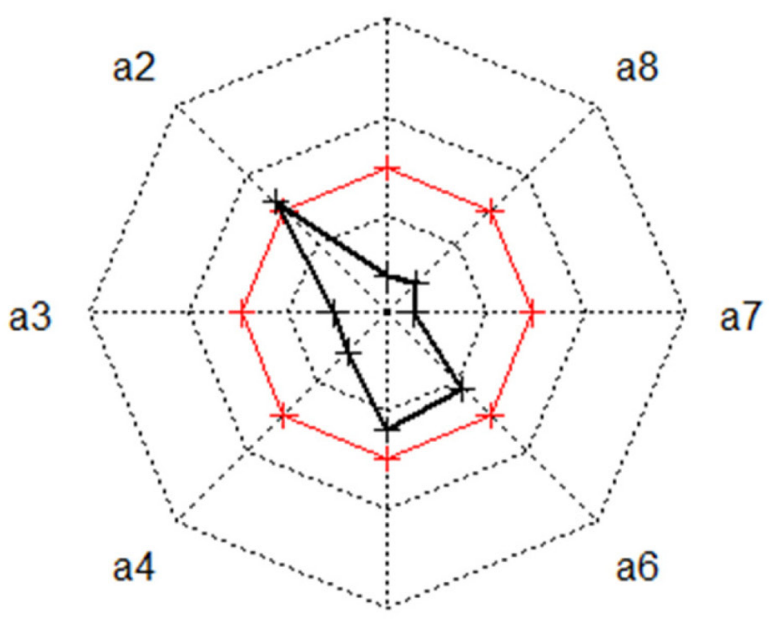

a5

The red line represents the overall mean of the 49 clones evaluated, and the black line represents the performance of the clone in question in the eight environments evaluated (al, a2, a3, a4, a5, a6, a7, and a8).

Figura 3. Graphical representation of Eucalyptus wood volume of clones 7, 22, 18, and 19 evaluated in eight environments. Standardized average data.

Figure 3. Representação gráfica do volume de madeira de eucalipto dos clones 7, 22, 18 e19 avaliados em oito ambientes. Dados médios padronizados.

For a forestry company with thousands of hectares in production annually, it would also be important to identify clones with specific adaptation, that is, use the occurrence of interaction for the benefit of selecting clones. Thus, in the Aracruz environments, although the interaction was significant, clone 8 was chosen especially in environments 1 and 3. Another clone that stood out in this region was 49. These two clones were selected in that region. Clone 22, selected in Três Lagoas, was among the top performers in the Jacareí and Três Lagoas environments.

\section{CONCLUSIONS}

The clones showed great variation in performance of volume production in different environments.

The clone $\mathrm{x}$ environment interaction was expressive, showing that, with regards to volumetric performance, the response of the clones did not coincide in the different sites. 
The response to environmental factors varied among clones, especially for altitude, rainfall, boron, and zinc.

For most of the clones, their selection site did not provide greater adaptation to their region of origin.

Clones 8 and 22 stood out as the most stable and adapted to the three regions of planted forest use. Other clones can be recommended for specific environments.

\section{ACKOWLEDGMENTS}

The data to carry out this study were kindly provided by Fibria Celulose S.A. We also thank the National Council of Technological and Scientific Development (CNPq) for scholarships.

\section{REFERENCES}

ALLARD, R. W.; BRADSHAW, A. D. Implications of genotype-environmental interactions in applied plant breeding. Crop Science, Madison, v. 4, p. 503-508, Sept 1964.

ANDRADE, H. B.; RAMALHO, M. A. P.; BUENO FILHO, J. S.; RESENDE, M. D. V.; XAVIER, A.; SCOLFORO, J. R. S. Alternativas para atenuar a diferença de estande nos experimentos de avaliação de clones de Eucalyptus urophylla. Revista Árvore, Viçosa, v. 30, n. 1, p. 11-18, 2006.

BERNARDO, R. Breeding for quantitative traits in plants. Stemma: Hardbound, 2010. 369 p.

CRUZ, C. D. GENES - a software package for analysis in experimental statistics and quantitative genetics. Acta Scientiarum, Maringá, v. 35, n. 3, p.271-276, 2013.

CRUZ, C. D.; REGAZZI, A. J.; CARNEIRO, P. C. S. Modelos biométricos aplicados ao melhoramento genético. 3. ed. Viçosa: UFV, 2004. 480 p.

FERREIRA, R. A. D.; RAMALHO, M. A. P.; TOLEDO, F. H. R. B.; ABREU, A. F. B. Implications of the number of years assessment on recommendation of common bean cultivars. Plant Breeding, v. 134, n. 5, p. 599-604, 2015.

IBÁ - INDÚSTRIA BRASILEIRA DE ÁRVORES. Anuário Estatístico da Indústria Brasileira de Árvores: ano base 2014. Brasília: IBA, 2015. 97 p.

KANG, M. S.; GAUCH, H. G. Genotype by Environment Interaction. Boca Raton: CRC Press, 1996. 416 p.

KANG, M. S.; MILLER, J. D. Genotype $\times$ environment interactions for cane and sugar yield and their implications in sugarcane breeding. Crop Science, Madison, v. 24, p. 435-440, 1984.

LIN, C. S.; BINNS, M. R.; LEFKOVICTH, L. P. Stabitity analysis. Where do we stand? Crop Science, Madison, v. 26, n. 5, p. 894-899, 1986.

MACHADO, S. A.; FIGUEIREDO FILHO, A. Dendrometria. 2. ed. Curitiba: UFPR, 2009. 316 p.

MENDES, M. H. S.; ROSSE, L. N.; TOLEDO, F. H. R. B.; RAMALHO, M. A. P. Experimental strategies for clonal Eucalyptus. Silvae Genetica, Frankfurt, v. 63, n. 1-2, p. 32-38, 2014.

NUNES, J. A. R.; RAMALHO, M. A. P.; ABREU, A. F. B. Graphical method in studies of adaptability and stability of cultivars. In: BIC. Annual Report of the Bean Improvement Cooperative 2004. Michigan: BIC, 2005. v. 48. p. $182-183$. 
Souza et al. - Performance of Eucalyptus clones according to environmental conditions

NUNES, G. H. S.; REZENDE, G. D. S. P.; RAMALHO, M. A. P.; SANTOS, J. B. Implicações da Interação genótipos x ambientes na seleção de clones de eucalipto. Cerne, Lavras, v. 8, n. 1, p. 49-58, 2002.

PIROLA, L. H.; RAMALHO, M. A. P.; CARNEIRO, J. E. S.; ABREU, A. F. B. Natural selection and family x location interaction in the common (dry) bean plant. Genetics and Molecular Biology, Ribeirão Preto, v. 25, n. 3, p.343-347, 2002.

R DEVELOPMENT CORE TEAM. R: A Language and Environment for Statistical Computing. Vienna: R Foundation for Statistical Computing, 2015. Disponível em: < http://www.R-project.org/ > .

RAMALHO, M. A. P.; ABREU, A. F. B.; SANTOS, J. B. dos; NUNES, J. A. R. Aplicações da genética quantitativa no melhoramento de plantas autógamas. Lavras: UFLA, 2012. 522 p.

RESENDE, M. D. V. Genética biométrica e estatística no melhoramento de plantas perenes. Brasília: Embrapa Informação Tecnológica, 2002. 975 p.

RESENDE, M. D. V.; DUARTE, J. B. Precisão e controle de qualidade em experimentos de avaliação de cultivares. Pesquisa Agropecuária Tropical, Goiânia, v. 37, p. 182-194, 2007.

ROCHA, R. B.; MURO ABAD, J. I.; ARAÚJO, E. F.; CRUZ, C. D. Avaliação do método centróide para estudo de adaptabilidade ao ambiente de clones de Eucalyptus grandis. Ciência Florestal, Santa Maria, v. 15, n. 3, p. 255-266, 2005.

SCOLFORO, J. R. S. Biometria Florestal: Parte I: modelos de regressão linear e não linear; Parte II: modelos para relação hipsométrica, volume, afilamento e peso de matéria seca. Lavras: UFLA/FAEPE, 2005, 325 p.

SANTOS, G. A. Interação genótipos $\mathrm{x}$ ambientes para produtividade de híbridos multi-espécies de eucalipto no Rio Grande do Sul. 2012. 128 p. Tese (Doutorado em Ciências Florestais) - Setor de Ciências Agrárias, Universidade Federal do Paraná, Curitiba, 2012.

SCOTT, A. J.; KNOTT, M. A cluster analysis method for grouping means in the analysis of variance. Biometrics, Washington, v. 30, n. 2 p. 507-512, 1974.

SILVA, C. A.; ABREU, A. F. B.; RAMALHO, M. A. P.; CARNEIRO, J. E. S. Implicações da origem das linhagens de feijoeiro na magnitude da interação com ambientes. Pesquisa Agropecuária Brasileira, Brasília, v. 46, n.7, p.720-728, 2011.

SOUZA, S. M.; SILVA, H. M.; PINTO JÚNIOR, J. E. Variabilidade genética e interação genótipo x ambiente em Eucalyptus pilularis. Boletim de Pesquisa Florestal, Colombo, n. 26/27, p. 3-16, 1993.

TROYER, A. F. Breeding widely adapted, popular maize hybrids. Euphytica, Wageningen, v. 92, n. 1, p. 163$174,1996$.

VENCOVSKY, R.; BARRIGA, P. Genética biométrica no fitomelhoramento. Ribeirão Preto: Sociedade Brasileira de Genética, 1992. 416 p.

WRICKE, G. Zur Berechnung der Ökovalenz bei Sommerweizen und Hafer. Zeitschrift für Pflanzenzüchtung, Berlin, v. 52, p.127-138, 1964.

Recebido em 29/11/2016

Aceito para publicação em 07/06/2017 